\title{
INFLUENCE OF SOME METEOROLOGICAL FACTORS IN THE INCIDENCE OF POLIOMYELITIS
}

\author{
BY \\ C. C. SPICER \\ Central Public Health Laboratory, Colindale, London
}

The seasonal variation in the incidence of poliomyelitis in temperate climates is one of the most obvious characteristics of the disease. A number of explanations of this have been put forward, for example by Aycock (1930), Petersen (1941), and Armstrong (1950). These explanations are mainly based on association in the average monthly trends and this approach is suspect statistically since it would almost always be possible to find some factor, meteorological or otherwise, with a similar seasonal distribution to poliomyelitis but with no necessary causal relation to the disease. Armstrong (1950), for example, shews that the seasonal variation in absolute humidity is closely parallel to that of poliomyelitis in eastern North America and goes on to produce an ingenious physiological explanation of why this should be so. Petersen (1941), by a similar type of argument, suggests solar radiation as the effective agent. Bradley and Richmond (1953), on the other hand, from a study of the English experience from 1947-50, have concluded that there is no obvious relationship between the incidence of the disease and the dry bulb temperature and absolute humidity.

Lawrence (1956) showed that there was a strong positive correlation between the total yearly notifications and the yearly mean dry bulb temperatures in the period 1947-52, and also between temperature and maximum weekly notifications. However, he also quotes some unpublished studies by the Meteorological Office which demonstrated little correlation between poliomyelitis incidence and temperature or relative humidity.

The present paper sets out to apply a statistical method which avoids some of the obvious pitfalls that beset the comparison of seasonal trends. It also allows an estimate to be made of how far the effect of associated meteorological variables is able to account for the actual range of variation of the incidence of the disease.

\section{Materials AND Methods}

The basic information used in the present study was derived from the Registrar General's uncorrected weekly notifications of poliomyelitis, and from the Meteorological Office records. The calendar month was taken as the unit of time as this was convenient in abstracting records and sufficiently long to smooth out some of the minor irregularities of weekly reporting. It is somewhat inconvenient in being irregular in length, but if this is ignored the effect on the results is negligible.

Before analysis the monthly poliomyelitis figures were converted to logarithms to the base 10 . This step was taken to even out the variability from one part of the year to another. There are great variations in the monthly incidence of poliomyelitis and changes in the absolute number of cases in midsummer are often large compared with those in the winter though the relative changes are of the same order.

The investigation was begun using the meteorological data collected by Bradley and Richmond (1953) and supplied by Captain F. H. Bradley of the Ministry of Health. When the analysis was extended up to 1956 the relevant figures were extracted from the Meteorological Office records at Harrow by permission of the Director. The final figures used are monthly averages of four daily readings taken at London Airport, Plymouth, Tynemouth, and Manchester, the temperature is in degrees Fahrenheit, and vapour pressure in millibars.

Bradley and Richmond (1953) confined their investigation to the effects of dry bulb temperature and absolute vapour pressure but the present study includes also the relative humidity obtained roughly from a graph of the relation between saturation vapour pressure and temperature plotted from figures given by Penman (1955).

The statistical methods used were largely suggested by the examples and discussion given in Chapter II 
of Quenouille (1952). In most time series analyses it is usual to remove the seasonal and long-term trends in the variables whose interrelations are being investigated and to base the conclusions on associations between the residual deviations from these fitted trends. What method of trend elimination is used is to some extent a matter of convenience. The method used here was to remove the average effect of months and years by the usual analysis of variance technique of fitting constants. This approach was particularly convenient for the machine computations, as the computer programme used prints out the residuals, after fitting the constants, which can then be used for correlation studies.

An alternative method would have been to fit trigonometrical regressions to the monthly values of the variables (Bliss, 1958; Aitken, 1939) and to correlate the deviations from these. However, it was found for poliomyelitis that there were significant variations from year to year in both amplitude and phase of a fitted Fourier series, and that more than two harmonics were required for an adequate fit; so, for simplicity, the method of fitting constants was used to provide the residuals.

Most of the computing was done on the Elliott 401 Mk I digital computer at Rothamsted Experimental Station. Mr. R. H. Tizard kindly provided a programme with which serial correlations were computed on the English Electric "Deuce" machine.

The analysis was based mainly on Table I (opposite), which shews the log mean weekly incidence of poliomyelitis (paralytic and non-paralytic) in England and Wales by calendar months for the years 1947-1956, together with the corresponding values of dry bulb temperature in degrees Fahrenheit, absolute vapour pressure in millibars, and relative humidity. The log poliomyelitis incidence was analysed not only in relation to the corresponding month's meteorological variables but also in relation to those of the two previous months. For this purpose extra values of the meteorological factors, outside the range of Table I, were extracted from the records. The variances and co-variances between the residuals of these variables after removal of yearly and monthly trends are given in Table II, which is, in effect, the "error" line of a table of the analysis of co-variance with 99 degrees of freedom.

\section{RESULTS}

The results of the regression analysis of the residuals are summarized in Table III. This gives the coefficients of the multiple linear regression of poliomyelitis residuals on the temperature and the relative humidity residuals of the same month and the two preceding months, together with their standard errors.

\section{TABLE III}

COEFFICIENTS OF MULTIPLE REGRESSION OF LOG POLIOMYELITIS RESIDUALS ON RESIDUALS OF TEMPERATURE $\left(b_{1}-b_{3}\right)$ AND RELATIVE HUMIDITY $\left(b_{4}-b_{6}\right)$ IN SAME AND TWO PREVIOUS MONTHS

\begin{tabular}{c|ll|l}
\hline & \multicolumn{2}{l}{ Coefficients of Multiple Regression } \\
\hline \multirow{3}{*}{ Temperature } & In same month & $b_{1}$ & $+0.017 \pm 0.008$ \\
& In previous month & $b_{2}$ & $+0.025 \pm 0.008$ \\
& In next previous month & $b_{3}$ & $+0.012 \pm 0.008$ \\
\hline \multirow{3}{*}{$\begin{array}{ll}\text { Relative } \\
\text { Humidity }\end{array}$} & In same month & $b_{4}$ & $-0.015 \pm 0.006$ \\
In previous month & $b_{s}$ & $-0.009 \pm 0.006$ \\
& In next previous month & $b_{6}$ & $-0.007 \pm 0.006$ \\
\hline
\end{tabular}

Table IV (opposite) gives the corresponding analysis of variance showing that about 36 per cent. of the variation in the poliomyelitis residuals can be accounted for by its association with the meteorological variables.

The absolute vapour pressure has been omitted from this regression as a preliminary analysis showed that it was of comparatively small importance. For example, the second order partial correlation between poliomyelitis incidence and the absolute vapour pressure, after eliminating the current month's relative humidity and the previous month's temperature, was $0 \cdot 1915$, which is not statistically significant

TABLE II

VARIANCES AND CO-VARIANCES OF LOG POLIOMYELITIS RESIDUALS AND TEMPERATURE AND RELATIVE HUMIDITY IN THE SAME AND TWO PREVIOUS MONTHS

\begin{tabular}{|c|c|c|c|c|c|c|c|}
\hline \multirow[b]{2}{*}{ Variable } & \multirow{2}{*}{$\begin{array}{c}\underset{\text { Log }}{\text { Poliomyelitis }} \\
\text { Incidence } \\
P\end{array}$} & \multicolumn{3}{|c|}{ Temperature } & \multicolumn{3}{|c|}{ Relative Humidity } \\
\hline & & $\begin{array}{c}\text { In same } \\
\text { month } \\
t_{0}\end{array}$ & $\begin{array}{c}\text { In previous } \\
\text { month } \\
t_{1}\end{array}$ & $\begin{array}{c}\text { In next } \\
\text { previous month } \\
t_{2}\end{array}$ & $\begin{array}{c}\text { In same } \\
\text { month } \\
r_{0}\end{array}$ & $\begin{array}{c}\text { In previous } \\
\text { month } \\
r_{1}\end{array}$ & $\begin{array}{c}\text { In next } \\
\text { previous month } \\
r_{2}\end{array}$ \\
\hline $\begin{array}{l}P \\
t_{0} \\
t_{1} \\
t_{2} \\
r_{0} \\
r_{1} \\
r_{2}\end{array}$ & 4.0936 & $\begin{array}{c}15 \cdot 569 \\
534 \cdot 78\end{array}$ & $\begin{array}{l}21 \cdot 671 \\
177 \cdot 18 \\
541 \cdot 99\end{array}$ & $\begin{array}{c}16 \cdot 588 \\
76 \cdot 06 \\
160 \cdot 34 \\
527 \cdot 98\end{array}$ & $\begin{array}{c}-19 \cdot 27 \\
-82 \cdot 6 \\
-14 \cdot 23 \\
-180 \cdot 9 \\
762 \cdot 0\end{array}$ & $\begin{array}{r}-12.97 \\
-24.1 \\
-87.3 \\
-146.5 \\
77.0 \\
755.0\end{array}$ & $\begin{array}{r}-7.27 \\
39.50 \\
-16.9 \\
-104.6 \\
28.0 \\
95.0 \\
804.0\end{array}$ \\
\hline
\end{tabular}


TABLE I

MEAN WEEKLY LOG POLIOMYELITIS INCIDENCE (P), MEAN DRY BULB TEMPERATURE ( ${ }^{\circ}$.) (T) MEAN RELATIVE HUMIDITY (RH), AND MEAN VAPOUR PRESSURE (MILLIBARS) (VP), BY MONTHS, 1947-1956

\begin{tabular}{|c|c|c|c|c|c|c|c|c|c|c|c|c|}
\hline Year .. & . & 1947 & 1948 & 1949 & 1950 & 1951 & 1952 & 1953 & 1954 & 1955 & 1956 & Total \\
\hline January & $\begin{array}{r}\mathbf{P} \\
\mathbf{T} \\
\mathbf{R H} \\
\mathbf{V P}\end{array}$ & $\begin{array}{l}1.04 \\
37.6 \\
86 \\
6.7\end{array}$ & $\begin{array}{c}1 \cdot 71 \\
42 \cdot 3 \\
86 \\
7 \cdot 9\end{array}$ & $\begin{array}{c}1 \cdot 40 \\
42 \cdot 5 \\
85 \\
7 \cdot 9\end{array}$ & $\begin{array}{c}1 \cdot 72 \\
41 \cdot 4 \\
89 \\
7.9\end{array}$ & $\begin{array}{c}1 \cdot 56 \\
40.6 \\
87 \\
7.6\end{array}$ & $\begin{array}{c}1.48 \\
38.4 \\
84 \\
6.7\end{array}$ & $\begin{array}{c}1.48 \\
40.0 \\
87 \\
7.4\end{array}$ & $\begin{array}{c}1 \cdot 56 \\
38.8 \\
81 \\
6.7\end{array}$ & $\begin{array}{c}1 \cdot 36 \\
38 \cdot 7 \\
86 \\
7 \cdot 0\end{array}$ & $\begin{array}{c}1 \cdot 66 \\
39 \cdot 8 \\
87 \\
7.4\end{array}$ & $\begin{array}{c}14 \cdot 97 \\
400 \cdot 1 \\
858 \\
73 \cdot 2\end{array}$ \\
\hline February & $\begin{array}{r}\mathbf{P} \\
\mathbf{T} \\
\mathbf{V P}\end{array}$ & $\begin{array}{c}1.05 \\
30.5 \\
88 \\
5.1\end{array}$ & $\begin{array}{c}1 \cdot 47 \\
41 \cdot 1 \\
88 \\
7 \cdot 4\end{array}$ & $\begin{array}{l}1 \cdot 19 \\
43 \cdot 1 \\
80 \\
7 \cdot 7\end{array}$ & $\begin{array}{c}1 \cdot 57 \\
42 \cdot 8 \\
83 \\
7 \cdot 9\end{array}$ & $\begin{array}{c}1 \cdot 37 \\
38 \cdot 5 \\
86 \\
7 \cdot 0\end{array}$ & $\begin{array}{l}1.25 \\
39.0 \\
81 \\
6.6\end{array}$ & $\begin{array}{c}1 \cdot 32 \\
40 \cdot 5 \\
84 \\
7 \cdot 3\end{array}$ & $\begin{array}{c}1 \cdot 33 \\
38 \cdot 1 \\
85 \\
6 \cdot 8\end{array}$ & $\begin{array}{c}1 \cdot 18 \\
35 \cdot 8 \\
82 \\
6 \cdot 0\end{array}$ & $\begin{array}{c}1.35 \\
33.4 \\
81 \\
5.4\end{array}$ & $\begin{array}{c}13 \cdot 08 \\
382 \cdot 8 \\
838 \\
67 \cdot 2\end{array}$ \\
\hline March & $\begin{array}{r}\mathbf{P} \\
\mathbf{T H} \\
\mathbf{V P}\end{array}$ & $\begin{array}{c}0 \cdot 81 \\
39 \cdot 5 \\
87 \\
7 \cdot 3\end{array}$ & $\begin{array}{c}1 \cdot 31 \\
47 \cdot 0 \\
77 \\
8 \cdot 6\end{array}$ & $\begin{array}{c}1 \cdot 22 \\
42 \cdot 1 \\
85 \\
7 \cdot 8\end{array}$ & $\begin{array}{l}1.47 \\
45 \cdot 2 \\
81 \\
8.4\end{array}$ & $\begin{array}{l}1 \cdot 25 \\
40.4 \\
82 \\
7.0\end{array}$ & $\begin{array}{l}1 \cdot 26 \\
44 \cdot 5 \\
85 \\
8 \cdot 6\end{array}$ & $\begin{array}{c}1.44 \\
42.9 \\
76 \\
7.2\end{array}$ & $\begin{array}{c}1 \cdot 32 \\
43 \cdot 1 \\
82 \\
7 \cdot 8\end{array}$ & $\begin{array}{c}1.04 \\
38.6 \\
74.0 \\
6.0\end{array}$ & $\begin{array}{c}1 \cdot 20 \\
43 \cdot 5 \\
79 \\
7 \cdot 6\end{array}$ & $\begin{array}{c}12 \cdot 32 \\
426 \cdot 8 \\
808 \\
76 \cdot 3\end{array}$ \\
\hline April & $\begin{array}{r}\mathbf{P} \\
\mathbf{T} \\
\mathbf{R H} \\
\mathbf{V P}\end{array}$ & $\begin{array}{c}0.94 \\
47 \cdot 6 \\
76 \\
8.7\end{array}$ & $\begin{array}{l}1 \cdot 23 \\
48 \cdot 5 \\
75 \\
8 \cdot 8\end{array}$ & $\begin{array}{c}1 \cdot 06 \\
49 \cdot 8 \\
77 \\
9.5\end{array}$ & $\begin{array}{c}1 \cdot 35 \\
45 \cdot 9 \\
75 \\
8 \cdot 1\end{array}$ & $\begin{array}{c}1 \cdot 28 \\
44 \cdot 8 \\
71 \\
7 \cdot 3\end{array}$ & $\begin{array}{c}1 \cdot 35 \\
48 \cdot 6 \\
77 \\
9 \cdot 0\end{array}$ & $\begin{array}{c}1 \cdot 56 \\
45 \cdot 7 \\
75 \\
7 \cdot 9\end{array}$ & $\begin{array}{c}1 \cdot 17 \\
46 \cdot 3 \\
72 \\
7 \cdot 6\end{array}$ & $\begin{array}{c}1 \cdot 10 \\
47 \cdot 4 \\
77 \\
9 \cdot 0\end{array}$ & $\begin{array}{c}1 \cdot 23 \\
44 \cdot 6 \\
75 \\
7 \cdot 5\end{array}$ & $\begin{array}{c}12 \cdot 27 \\
469 \cdot 2 \\
750 \\
83.4\end{array}$ \\
\hline May & $\begin{array}{r}\mathbf{P} \\
\mathbf{T} \\
\mathbf{R H} \\
\mathbf{V P}\end{array}$ & $\begin{array}{l}1 \cdot 16 \\
54 \cdot 2 \\
78 \\
11 \cdot 4\end{array}$ & $\begin{array}{c}1 \cdot 28 \\
52 \cdot 4 \\
72.9 \\
9 \cdot 9\end{array}$ & $\begin{array}{c}1 \cdot 16 \\
51 \cdot 8 \\
74.9 \\
9 \cdot 9\end{array}$ & $\begin{array}{l}1 \cdot 50 \\
52 \cdot 6 \\
77 \\
10.5\end{array}$ & $\begin{array}{c}1 \cdot 40 \\
49 \cdot 5 \\
75 \\
9 \cdot 2\end{array}$ & $\begin{array}{l}1 \cdot 53 \\
54 \cdot 9 \\
75 \\
11 \cdot 2\end{array}$ & $\begin{array}{l}1 \cdot 59 \\
54 \cdot 3 \\
74 \\
10 \cdot 9\end{array}$ & $\begin{array}{l}1 \cdot 34 \\
51 \cdot 7 \\
78 \\
10 \cdot 2\end{array}$ & $\begin{array}{c}1 \cdot 34 \\
49 \cdot 4 \\
76 \\
9 \cdot 1\end{array}$ & $\begin{array}{c}1.48 \\
53 \cdot 5 \\
72.9 \\
9.9\end{array}$ & $\begin{array}{l}13 \cdot 78 \\
524 \cdot 3 \\
751 \\
102 \cdot 2\end{array}$ \\
\hline June & $\begin{array}{r}\mathbf{P} \\
\mathbf{T} \\
\mathbf{R P} \\
\mathbf{V P}\end{array}$ & $\begin{array}{l}1 \cdot 66 \\
58 \cdot 4 \\
79 \\
13 \cdot 2\end{array}$ & $\begin{array}{l}1 \cdot 36 \\
55 \cdot 9 \\
80 \\
12.4\end{array}$ & $\begin{array}{l}1 \cdot 61 \\
58 \cdot 4 \\
74 \\
12 \cdot 5\end{array}$ & $\begin{array}{l}2 \cdot 04 \\
60.0 \\
76 \\
13.6\end{array}$ & $\begin{array}{l}1 \cdot 81 \\
55 \cdot 5 \\
76 \\
11 \cdot 5\end{array}$ & $\begin{array}{l}1.83 \\
57.5 \\
74 \\
12.0\end{array}$ & $\begin{array}{l}1 \cdot 84 \\
56 \cdot 8 \\
83 \\
13 \cdot 2\end{array}$ & $\begin{array}{l}1 \cdot 59 \\
55 \cdot 7 \\
80 \\
12 \cdot 1\end{array}$ & $\begin{array}{l}1 \cdot 66 \\
56 \cdot 5 \\
78 \\
12 \cdot 1\end{array}$ & $\begin{array}{l}1 \cdot 78 \\
55 \cdot 2 \\
78 \\
11 \cdot 6\end{array}$ & $\begin{array}{l}17 \cdot 18 \\
569 \cdot 9 \\
778 \\
124 \cdot 2\end{array}$ \\
\hline July & $\begin{array}{r}\mathbf{P} \\
\mathbf{T} \\
\mathbf{V P}\end{array}$ & $\begin{array}{l}2 \cdot 38 \\
61 \cdot 2 \\
82 \\
15 \cdot 2\end{array}$ & $\begin{array}{l}1 \cdot 57 \\
59 \cdot 5 \\
80 \\
14 \cdot 0\end{array}$ & $\begin{array}{l}2 \cdot 06 \\
63 \cdot 1 \\
73 \\
14 \cdot 5\end{array}$ & $\begin{array}{l}2 \cdot 40 \\
60 \cdot 7 \\
80 \\
14 \cdot 6\end{array}$ & $\begin{array}{l}2 \cdot 07 \\
61 \cdot 3 \\
75 \\
14 \cdot 1\end{array}$ & $\begin{array}{l}2 \cdot 24 \\
61 \cdot 8 \\
74 \\
14 \cdot 3\end{array}$ & $\begin{array}{l}2 \cdot 34 \\
59 \cdot 6 \ldots \\
79 \\
13 \cdot 8\end{array}$ & $\begin{array}{l}1 \cdot 88 \\
57 \cdot 2 \\
80 \\
12 \cdot 7\end{array}$ & $\begin{array}{l}2 \cdot 20 \\
63 \cdot 2 \\
75 \\
14 \cdot 7\end{array}$ & $\begin{array}{l}2 \cdot 12 \\
59 \cdot 7 \\
81 \\
14 \cdot 1\end{array}$ & $\begin{array}{l}21 \cdot 26 \\
607 \cdot 3 \\
779 \\
142 \cdot 0\end{array}$ \\
\hline August & $\begin{array}{r}\mathbf{P} \\
\mathbf{T} \\
\mathbf{R H} \\
\mathbf{V P}\end{array}$ & $\begin{array}{l}2 \cdot 81 \\
64 \cdot 5 \\
74 \\
15 \cdot 5\end{array}$ & $\begin{array}{l}1 \cdot 78 \\
58 \cdot 8 \\
84 \\
14 \cdot 2\end{array}$ & $\begin{array}{l}2 \cdot 42 \\
62 \cdot 0 \\
77 \\
14 \cdot 7\end{array}$ & $\begin{array}{l}2 \cdot 69 \\
59 \cdot 7 \\
82 \\
14 \cdot 4\end{array}$ & $\begin{array}{l}2 \cdot 05 \\
58 \cdot 7 \\
79 \\
13 \cdot 5\end{array}$ & $\begin{array}{l}2 \cdot 37 \\
60 \cdot 0 \\
79 \\
14 \cdot 1\end{array}$ & $\begin{array}{l}2 \cdot 44 \\
60 \cdot 6 \\
79 \\
14 \cdot 3\end{array}$ & $\begin{array}{l}1 \cdot 93 \\
57 \cdot 7 \\
84 \\
13 \cdot 7\end{array}$ & $\begin{array}{l}2 \cdot 55 \\
64 \cdot 0 \\
77 \\
15 \cdot 5\end{array}$ & $\begin{array}{l}2 \cdot 16 \\
56 \cdot 4 \\
83 \\
12 \cdot 7\end{array}$ & $\begin{array}{l}23 \cdot 20 \\
602 \cdot 4 \\
798 \\
142 \cdot 6\end{array}$ \\
\hline September & $\begin{array}{r}\mathbf{P} \\
\mathbf{T} \\
\mathbf{R H} \\
\mathbf{V P}\end{array}$ & $\begin{array}{l}2 \cdot 76 \\
58 \cdot 9 \\
79 \\
13 \cdot 4\end{array}$ & $\begin{array}{l}1 \cdot 88 \\
57 \cdot 1 \\
81 \\
13 \cdot 1\end{array}$ & $\begin{array}{l}2 \cdot 51 \\
61 \cdot 4 \\
82 \\
15 \cdot 4\end{array}$ & $\begin{array}{l}2 \cdot 64 \\
55 \cdot 7 \\
83 \\
12 \cdot 7\end{array}$ & $\begin{array}{l}1.97 \\
57.9 \\
82 \\
13.5\end{array}$ & $\begin{array}{l}2 \cdot 25 \\
53 \cdot 1 \\
76 \\
10 \cdot 7\end{array}$ & $\begin{array}{l}2 \cdot 31 \\
56 \cdot 9 \\
83 \\
13 \cdot 2\end{array}$ & $\begin{array}{l}1 \cdot 91 \\
55 \cdot 1 \\
81 \\
12.0\end{array}$ & $\begin{array}{l}2 \cdot 61 \\
57 \cdot 8 \\
79 \\
12.9\end{array}$ & $\begin{array}{l}2 \cdot 06 \\
57 \cdot 7 \\
86 \\
14 \cdot 0\end{array}$ & $\begin{array}{l}22.90 \\
571.6 \\
812 \\
130.9\end{array}$ \\
\hline October & $\begin{array}{r}\mathbf{P} \\
\mathbf{T} \\
\mathbf{R H} \\
\mathbf{V P}\end{array}$ & $\begin{array}{l}2 \cdot 50 \\
52 \cdot 4 \\
81 \\
11 \cdot 1\end{array}$ & $\begin{array}{l}1.91 \\
50.7 \\
84 \\
10.8\end{array}$ & $\begin{array}{l}2 \cdot 60 \\
54 \cdot 6 \\
83 \\
12 \cdot 3\end{array}$ & $\begin{array}{l}2.46 \\
50.3 \\
86 \\
10.8\end{array}$ & $\begin{array}{l}2.00 \\
50.6 \\
83 \\
10.5\end{array}$ & $\begin{array}{c}2 \cdot 05 \\
48 \cdot 3 \\
84.8 \\
9 \cdot 8\end{array}$ & $\begin{array}{l}2 \cdot 15 \\
50 \cdot 2 \\
87 \\
10 \cdot 8\end{array}$ & $\begin{array}{l}1.84 \\
53.9 \\
86 \\
12.3\end{array}$ & $\begin{array}{c}2 \cdot 54 \\
49 \cdot 2 \\
81 \\
9 \cdot 8\end{array}$ & $\begin{array}{l}2 \cdot 14 \\
50 \cdot 0 \\
84 \\
10.5\end{array}$ & $\begin{array}{l}22 \cdot 19 \\
510 \cdot 2 \\
839 \\
108 \cdot 7\end{array}$ \\
\hline November & $\begin{array}{r}\mathbf{P} \\
\mathbf{T} \\
\mathbf{R H} \\
\mathbf{V P}\end{array}$ & $\begin{array}{c}2 \cdot 22 \\
45 \cdot 8 \\
86 \\
9 \cdot 2\end{array}$ & $\begin{array}{l}1 \cdot 77 \\
46 \cdot 4 \\
90 \\
9 \cdot 8\end{array}$ & $\begin{array}{c}2 \cdot 39 \\
45 \cdot 7 \\
81 \\
8 \cdot 7\end{array}$ & $\begin{array}{c}2 \cdot 22 \\
43 \cdot 1 \\
87 \\
8 \cdot 4\end{array}$ & $\begin{array}{l}1 \cdot 82 \\
48 \cdot 7 \\
85 \\
10 \cdot 0\end{array}$ & $\begin{array}{c}1.97 \\
40.9 \\
85 \\
7.4\end{array}$ & $\begin{array}{l}1.94 \\
47.9 \\
87 \\
10.0\end{array}$ & $\begin{array}{l}1 \cdot 75 \\
45 \cdot 7 \\
85 \\
9 \cdot 1\end{array}$ & $\begin{array}{c}2 \cdot 28 \\
46 \cdot 0 \\
84 \\
9 \cdot 1\end{array}$ & $\begin{array}{c}1 \cdot 98 \\
44 \cdot 3 \\
84 \\
8 \cdot 4\end{array}$ & $\begin{array}{c}20 \cdot 34 \\
454 \cdot 5 \\
854 \\
90 \cdot 1\end{array}$ \\
\hline December & $\begin{array}{r}\mathbf{P} \\
\mathbf{T} \\
\mathbf{R H} \\
\mathbf{V P}\end{array}$ & $\begin{array}{c}1 \cdot 82 \\
43 \cdot 4 \\
85 \\
8 \cdot 3\end{array}$ & $\begin{array}{l}1 \cdot 49 \\
43.4 \\
86 \\
8.4\end{array}$ & $\begin{array}{c}2 \cdot 00 \\
44 \cdot 0 \\
82 . j \\
8 \cdot 2\end{array}$ & $\begin{array}{c}1 \cdot 91 \\
35 \cdot 8 \\
86 \\
6 \cdot 3\end{array}$ & $\begin{array}{c}1 \cdot 56 \\
43 \cdot 3 \\
85 \\
8 \cdot 3\end{array}$ & $\begin{array}{c}1 \cdot 68 \\
39 \cdot 2 \\
86 \\
7 \cdot 1\end{array}$ & $\begin{array}{c}1 \cdot 70 \\
46 \cdot 6 \\
87 \\
9 \cdot 5\end{array}$ & $\begin{array}{c}1 \cdot 47 \\
45 \cdot 0 \\
84 \\
8 \cdot 7\end{array}$ & $\begin{array}{l}1 \cdot 95 \\
44 \cdot 1 \\
85 \\
8 \cdot 5\end{array}$ & $\begin{array}{l}1 \cdot 82 \\
44 \cdot 0 \\
88 \\
8 \cdot 8\end{array}$ & $\begin{array}{c}17 \cdot 40 \\
428 \cdot 8 \\
854 \\
82 \cdot 1\end{array}$ \\
\hline Total & $\begin{array}{r}\mathbf{P} \\
\mathbf{T} \\
\mathbf{R H} \\
\mathbf{V P}\end{array}$ & $\begin{array}{l}21 \cdot 15 \\
594 \cdot 0 \\
981 \\
125 \cdot 1\end{array}$ & $\begin{array}{l}18 \cdot 76 \\
603 \cdot 1 \\
983 \\
125 \cdot 3\end{array}$ & $\begin{array}{l}21 \cdot 62 \\
618 \cdot 5 \\
953 \\
129 \cdot 1\end{array}$ & $\begin{array}{l}23.97 \\
593 \cdot 2 \\
985 \\
123.6\end{array}$ & $\begin{array}{l}20 \cdot 14 \\
589 \cdot 8 \\
966 \\
119 \cdot 5\end{array}$ & $\begin{array}{l}21 \cdot 26 \\
586 \cdot 2 \\
960 \\
117 \cdot 5\end{array}$ & $\begin{array}{l}22 \cdot 11 \\
602 \cdot 0 \\
981 \\
125 \cdot 5\end{array}$ & $\begin{array}{l}19 \cdot 09 \\
588 \cdot 3 \\
978 \\
119 \cdot 7\end{array}$ & $\begin{array}{l}21 \cdot 81 \\
590 \cdot 7 \\
954 \\
119 \cdot 7\end{array}$ & $\begin{array}{l}20 \cdot 98 \\
582 \cdot 1 \\
978 \\
117 \cdot 9\end{array}$ & $\begin{array}{l}210 \cdot 89 \\
5947 \cdot 9 \\
9719 \\
1222 \cdot 9\end{array}$ \\
\hline
\end{tabular}

TABLE IV

ANALYSIS OF VARIANCE SHOWING VARIATION IN LOG POLIOMYELITIS RESIDUALS ASCRIBABLE TO TEMPERA TURE AND RELATIVE HUMIDITY IN SAME AND TWO

\begin{tabular}{|c|c|c|c|c|c|c|}
\hline \multicolumn{4}{|c|}{ Source of Variation } & $\begin{array}{l}\text { Sum of } \\
\text { Squares }\end{array}$ & $\begin{array}{l}\text { Degrees of } \\
\text { Freedom }\end{array}$ & $\begin{array}{c}\text { Mean } \\
\text { Squares }\end{array}$ \\
\hline $\begin{array}{l}\text { Regressio } \\
\text { and Relat }\end{array}$ & - & $\begin{array}{l}\text { mpe } \\
\text { idity }\end{array}$ & $\begin{array}{c}\text { ure } \\
.\end{array}$ & $1 \cdot 4721$ & 6 & $0 \cdot 2453$ \\
\hline Residual & . & $\ldots$ & $\cdots$ & $2 \cdot 5675$ & 93 & 0.0276 \\
\hline Total & $\ldots$ & $\ldots$ & .. & 4.0396 & & \\
\hline
\end{tabular}

on 96 degrees of freedom. The two variables eliminated are those most strongly correlated with polio- myelitis incidence and the introduction of others reduces the value of the correlation with vapour pressure still further.

It can be seen from Table III that, as judged by their standard errors, only the regression coefficients of poliomyelitis incidence on the current and previous months' temperature and the current month's 
relative humidity are statistically significant. However, the other three coefficients all exceed their standard errors and can be shown to contribute significantly in aggregate to the sum of squares for regression, so that some, at least, of the six variables appear to influence the current month's poliomyelitis. The effect of temperature and relative humidity more than two months before is negligible-incorporation of the third month only removes 0.01 from the sum of squares for poliomyelitis incidence, compared with a residual error of 0.03 .

The regression coefficients of poliomyelitis incidence on temperature and relative humidity given above were derived from the simultaneous variation in the residuals of these quantities after the main effects of years and seasons had been allowed for. It is interesting to see how far this regression can account for the seasonal variation. If the seasonal swing is due mainly to factors unconnected with temperature and relative humidity, then there is no reason to expect that the average seasonal incidence of poliomyelitis could be predicted from concomitant variation of poliomyelitis incidence and these two variables.

While it is possible that there might be a general similarity in the relative monthly incidence, it is nevertheless unlikely that the full range of seasonal variation would be predicted, or that there should be a close coincidence of the maxima of the two curves. To take a hypothetical example, a disease whose spread was favoured to some extent by cold weather, but which was largely disseminated in ice-cream, would show a high summer incidence quite unpredictable from its observed relation to meteorological factors over short periods of time throughout the year.

Expected values of the log poliomyelitis incidence in any given month can be derived using the regression coefficients given in Table III and the deviations about their general mean of the corresponding meteorological variables. The multiple regression equation is used in the form

$p=\bar{p}+b_{1}\left(t_{0}-\bar{t}\right)+b_{2}\left(t_{1}-\bar{t}\right)+\ldots+b_{4}\left(r_{0}-\bar{r}\right)+\ldots$ etc. where $\bar{p}$ is the mean poliomyelitis incidence, $\bar{t}$ the mean temperature, and $\bar{r}$ the mean relative humidity over the whole period of observation, $t_{0}, t_{1} \ldots, r_{0}, r_{1}$ ... etc. are the observed temperatures and relative humidities in the relevant months, and $b_{1}, b_{2} \ldots$ etc. have the values given in Table III.

The results of such a calculation are given in the Figure, which compares the average monthly incidence of poliomyelitis in the years 1947-56 with

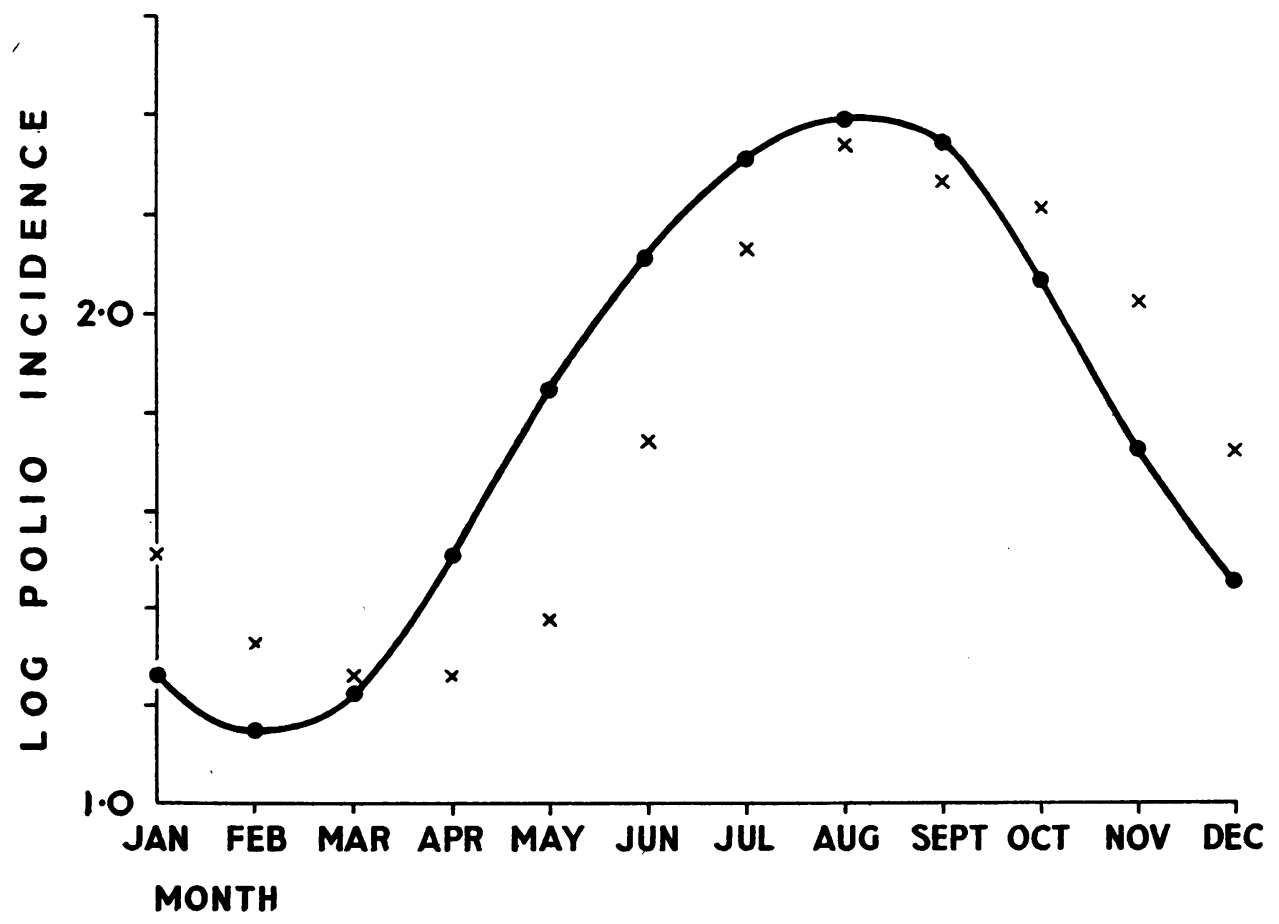

FIGURE. - Comparison of average monthly log poliomyelitis incidence, predicted from regression on temperature and relative humidity, with observed values $(x)$. 
that calculated from the monthly mean regression on temperatures and relative humidities, using the residual regression coefficients. It can be seen that there is a fair measure of agreement between the observed and calculated incidence. The range of the predicted curve is very close to the observed value and the position of the summer maximum coincides fairly well. On the other hand, the predicted minimum occurs considerably before the actual one, and the curve as a whole tends to be too high in the early part of the epidemic and too low in the latter part. The general nature of the discrepancy is not unexpected, since the disease tends to be under-notified in the early stages of the epidemic and over-notified later on when many cases are being reported. In addition, the epidemic must take on a momentum of its own, independent of meteorological factors, once it is well launched, and this will cause an excess of cases in the later stages and a corresponding deficit of cases at the beginning of the next seasonal rise due to exhaustion of the susceptible population.

The analysis presented so far applies to the whole period from 1947-1956. It is usual in studies with time series to repeat the analysis, as far as possible, separately for subsections of the series. This provides a check on the consistency of the analysis and is particularly important in a case like the present. The incidence of the disease in England and Wales is now much higher than before 1939, and may well have taken some time to reach equilibrium after the sudden change in incidence that occurred in 1947. Examination of the series does in fact show that the relation between poliomyelitis and meteorological variables is not constant from year to year. This is illustrated in Table V, where it can be seen that the relationship with temperature was very weak in the years 19491951, and also in 1953. One of the effects of this irregularity is that the results for paralytic poliomyelitis, for which figures are available only from 1950 onwards, show no significant correlation with temperature or humidity. This occurs largely because

\section{TABLE V}

CORRELATION COEFFICIENTS BETWEEN POLIOMYELITIS RESIDUALS AND PREVIOUS MONTH'S TEMPERATURE, 1947-1956

\begin{tabular}{c|c}
\hline Year & $r$ \\
\hline 1947 & +0.787 \\
1948 & +0.802 \\
1949 & +0.364 \\
1950 & +0.049 \\
1951 & +0.495 \\
1952 & +0.850 \\
1953 & +0.142 \\
1954 & +0.518 \\
1955 & +0.554 \\
1956 & +0.459 \\
\hline
\end{tabular}

they do not include the very high correlations found in 1947 and 1948, and similar considerations apply to notifications of non-paralytic poliomyelitis over the same period.

\section{Discussion}

The results reported above establish a prima facie case for a relationship between the incidence of poliomyelitis, temperature and relative humidity but provide no evidence that absolute vapour pressure is of much importance, in contradiction to the hypothesis of Armstrong (1950) regarding the nature of the relationship between incidence of the disease and climatic factors. On the other hand, the analysis does not exclude the possibility that other meteorological variables closely related to temperature and relative humidity are involved.

Generally speaking, the meteorological conditions favouring spread of the disease are those of rapid outdoor drying, though there does not seem to be any simple explanation of the fact that incidence of the disease is associated with meteorological conditions up to 2 months previously. As the regression coefficients calculated from the comparatively small scale monthly deviations are capable of explaining the yearly range of variation, it seems likely that the seasonal association with temperature is not related only to the greater physical activity and freer mixing of the population that occurs in the summer months. A possible hypothesis is that atmospheric conditions of rapid drying favour survival of the virus in faeces, and one suggestion that arises from the present study is that this should be put to experimental test.

The statistical validity of the analysis is by no means beyond question. The main point inits favour is that the regression coefficients calculated from the residuals are capable of explaining the range of seasonal variation in the incidence of the disease and the position of the maximum. The deviations from prediction are such as might be expected to occur on other grounds, though there is no method of assessing how large the expected deviations should be.

The main statistical weaknesses are the variations in the strength of the relationship between poliomyelitis incidence and meteorological factors from year to year, which arise through ignoring interactions in the analysis of co-variance, and through the presence of considerable serial correlations in the residuals. The latter can to some extent be allowed for by statistical methods, their effect being to reduce the apparent number of observations by a factor depending in the strength of the correlations. Using the method given by Quenouille (1952), it was 
found that the effective number of degrees of freedom were reduced by about 50 per cent., which is not sufficient to destroy the formal significance of the correlation between poliomyelitis incidence, temperature, and relative humidity.

The general pattern of the variation from year to year in the correlations between meteorological factors and poliomyelitis is illustrated in Table V, which shows the correlation coefficients between the residuals of poliomyelitis and previous month's temperature, calculated separately for each year. It is obvious that the relationship is not stable, and a z-test reveals that there are significant variations in the coefficients. The correlations are all positive, except in 1951, and mostly of reasonable size; this supports the existence of a positive relationship, but it seems probable that the strength and nature of this association are not the same from year to year. However, the ability of the regression equation to account for the mean seasonal variation of the disease over a 10-year period suggests that there may be a stable underlying relationship. For further corroboration it would be interesting to extend this work in future years and also to make similar investigations on other countries with a greater range of yearly variation in the meteorological factors under consideration.

\section{SUMMARY}

An analysis has been made of the relationship between the incidence of poliomyelitis in England and Wales from 1947 to 1956 and various meteorological factors.
It was found that there were strong positive correlations with dry bulb temperature and negative correlations with relative humidity, but that absolute vapour pressure was not related to the incidence of poliomyelitis. The calculated relationship with temperature and relative humidity was able to account for the main seasonal range and also for the time of the maximum incidence.

The results and methods of analysis are critically discussed.

I am greatly indebted to the Statistics Department at Rothamsted Experimental Station and particularly to Mr. M. J. R. Healy for help in analysing much of the data on the electronic computer there. I am also grateful to Mr. R. H. Tizard and Miss J. Grahame for calculating serial correlations on the English Electric Deuce machine. Mr. R. G. Veryard and Mr. E. N. Lawrence of the Air Ministry Meteorological Office, Harrow, have allowed me to make use of the records there and were most helpful in abstracting them. Captain F. H. Bradley of the Ministry of Health kindly supplied me with the figures for 1947-52. Finally, I must thank Miss Molly Fretton who has assisted me throughout with the calculations and the abstracting of records.

\section{REFERENCES}

Aitken, A. C. (1939). "Statistical Mathematics", 1st ed. Oliver anđ Boyd, Edinburgh.

Armstrong, C. (1950). Amer. J. publ. Hlth, 40, 1296.

Aycock, W. L. (1930). Ibid., 20, 41 .

Bliss, C. I. (1958). Bull. Conn. agric. Exp. Sta., No. 615.

Bradley, W. H., and Richmond, A. E. (1953). Monthly Bull. Minist. Hlth Lab. Serv., 12, 2.

Lawrence, E. N. (1956). Met. Mag. Lond., 85, 164.

Penman, H. L. (1955). "Humidity". Institute of Physics, London.

Petersen, H. (1941). Acta med. scand., 107, 282.

Quenouille, M. H. (1952). "Associated Measurements". Butterworth London. 